\title{
JOINT COMMISSION OF THE EMPRESS SHÔKEN FUND
}

\author{
CIRCULAR No. 83
}

Geneva, 11 April 1992

\author{
To all National Red Cross and Red Crescent Societies
}

\section{Seventy-first distribution of income}

The Joint Commission entrusted with the distribution of the income of the Empress Shôken Fund met in Geneva on 8 April 1992. The Ambassador and Permanent Representative of Japan in Geneva, His Excellency Mr. Hidetoshi Ukawa, attended the meeting as an observer representing also the Japanese Red Cross Society.

The Commission approved the statement of accounts on the situation of the Fund as at 31 December 1991 and noted that the balance available amounted to 402,987 Swiss francs, and decided to increase it by 18,000 francs corresponding to the amount of an unspent allocation made in 1990 (69th distribution).

In examining the 36 projects presented by 29 National Societies, as well as three regional projects, the Joint Commission took into account the criteria revised and completed in 1990 on the basis of experience gained over the last few years. These criteria are designed to:

(1) restrict the number of allocations so that the amounts allocated for each are sufficient to enable the approved projects to be successfully implemented;

(2) give priority to developing Societies and, among them, to those that have least benefited from the Fund or, according to objective criteria, are in greatest need thereby maintaining a reasonable degree of regional balance. 
It is thus possible:

(a) to finance, up to a maximum of half of the funds available, projects to develop the human resources of the candidate Societies (scholarships, training courses benefiting volunteers and paid staff members of both sexes equally);

(b) to finance, up to a maximum of half of the funds available, purchases of material and equipment clearly corresponding to the objectives of the Fund (Art. 3 of the Regulations), apart from means of transport;

(c) to restrict allocations earmarked for the purchase of means of transport (vehicles, ambulances, etc.), including spare parts, to half the funds available;

(d) also to take into consideration one or more projects for a regional programme previously approved by the beneficiary Societies, the International Federation and/or the ICRC. A maximum of 100,000 Swiss francs can be allocated each year, and this for up to five years. Every further allocation is subject to the submission of satisfactory progress reports by the beneficiary Societies;

(e) to exclude requests from Societies that have not provided satisfactory reports on the use of a previous allocation from the Fund.

The Joint Commission decided to make the following grants:

$\begin{array}{lcc}\text { Beneficiary } & \text { Amount in } & \text { Purpose of allocation } \\ \text { National } & \text { Swiss francs } & \\ \text { Society } & & \end{array}$

\begin{tabular}{|c|c|c|}
\hline Afghanistan & 72,000 & $\begin{array}{l}\text { Partial financing for the construction } \\
\text { of a dispensary }\end{array}$ \\
\hline Bolivia & 25,000 & $\begin{array}{l}\text { Partial financing for the purchase of } \\
\text { training and first-aid material }\end{array}$ \\
\hline Dominica & 20,000 & $\begin{array}{l}\text { Partial financing for the purchase of a } \\
\text { multi-purpose vehicle }\end{array}$ \\
\hline Liberia & 42,000 & $\begin{array}{l}\text { Purchase of a Toyota Land Cruiser } \\
\text { ambulance }\end{array}$ \\
\hline Nepal & 54,000 & $\begin{array}{l}\text { Partial financing of the Society's } \\
\text { ambulance service }\end{array}$ \\
\hline
\end{tabular}




\begin{tabular}{lrl}
$\begin{array}{l}\text { Beneficiary } \\
\text { National } \\
\text { Society }\end{array}$ & $\begin{array}{c}\text { Amount in } \\
\text { Swiss francs }\end{array}$ & \multicolumn{1}{c}{ Purpose of allocation } \\
\hline Paraguay & 25,000 & $\begin{array}{l}\text { Partial financing for the purchase of } \\
\text { training and first-aid material }\end{array}$ \\
$\begin{array}{l}\text { St. Vincent \& } \\
\text { Grenadines }\end{array}$ & 40,000 & $\begin{array}{l}\text { Installation of radio equipment to link } \\
\text { HQ with the outlying districts }\end{array}$ \\
$\begin{array}{l}\text { Togo } \\
\text { West \& Central } \\
\text { Africa } \\
\text { (Benin, }\end{array}$ & 42,000 & $\begin{array}{l}\text { Purchase of a Toyota Hiace ambulance } \\
\text { Cover two-thirds of the Federation's }\end{array}$ \\
\hline
\end{tabular}

\section{Burkina Faso,} Congo, Côte d'Ivoire, Guinea, Liberia and Sierra Leone)

$$
\text { Total } \overline{420,000}
$$

The unused balance of 987 Swiss francs will be added to the income available for the 72nd distribution (1993).

Depending on market conditions, the Joint Commission will decide whether purchase arrangements will be made by the Federation's Logistics Service or directly by the beneficiary Society.

If a purchase on the local market has been envisaged or decided, the National Society shall submit to the Joint Commission an original offer or pro forma invoice, in English, French or Spanish indicating a reliable date of delivery. If applicable, and in accordance with internationally accepted business rules, the Joint Commission will transfer $50 \%$ of the indicated price to enable the National Society to place the order. The balance will be transferred only upon receipt of the seller's or manufacturer's delivery form and of the final invoice on which the initial down payment is duly entered.

Pursuant to the Fund's Regulations, each beneficiary Society must submit to the Joint Commission a report on results achieved in using the equipment purchased with the grant. The Joint Commission requests that these descriptive reports be sent not later than twelve months after receiving the allocation, accompanied, if possible, by photographs illustrating the activities carried out thanks to the allocation. The report should show whether the allocation has enabled the Society to implement the programme, and whether the programme 
has in fact met the needs of the population, so that the Joint Commission is in a position to form an opinion on results achieved.

The Joint Commission reminds beneficiary Societies of Article 6 of the Regulations which prohibits the assigning of the grant for purposes other than those specified without the prior consent of the Joint Commission.

Allocations remaining unclaimed or unused after twelve months will be withdrawn and added to the amount available for the next distribution.

\section{2nd distribution -1993}

The 1992 income will be distributed in 1993. To help National Societies file their applications in conformity with the Regulations, the Joint Commission will mail model application forms to all National Societies in August. It will also provide National Societies with criteria and guidelines regarding projects that could be financed - wholly or partly - by the Empress Shôken Fund.

Requests for allocations must be submitted to the Secretariat of the Joint Commission before 31 December 1992.

For the Joint Commission

International Committee of the Red Cross

M. Aubert (Chairman)

M. Martin

S. Nessi
International Federation of Red Cross and Red Crescent Societies

P. Stenbäck

B. Bergman

S. Davey

P. Tischhauser (Secretary) 